\title{
"ERNESTO DE TAL": O AMOR, O CASAMENTO POR CONVENIÊNCIA E O CONSÓRCIO ENTRE AS INSTITUIÇÕES SOCIAIS
}

\section{NAIARA SANTANA PITA}

Universidade Federal da Bahia

Salvador, Bahia, Brasil

\section{MIRELLA MÁRCIA LONGO VIEIRA LIMA}

Universidade Federal da Bahia

Salvador, Bahia, Brasil

Resumo: Nesse estudo, procuramos localizar as tensões entre a sociedade de classes e os estamentos vindos da Colônia e permanentes no Brasil. A análise é encaminhada no sentido de mostrar como Machado de Assis deslinda a exigência de casamento para as mulheres dentro da sociedade senhorial brasileira. $\mathrm{O}$ autor traz como pano de fundo os efeitos que as mudanças políticas ocorridas no Brasil oitocentista tiveram na vida dos personagens centrais. A visão do amor é desromantizada e o afeto sincero é visto como motivo de vergonha. Assim, procurou-se apresentar como ocorreu a entronização do modelo burguês em uma sociedade patriarcal e escravista. Dessa associação, vimos uma solução que resulta, se não em malogro do projeto moderno, em, pelo menos, sua deformação.

Palavras-chave: Machado de Assis; dinheiro; casamento; século XIX. 


\title{
"ERNESTO DE TAL": LOVE, MARRIAGE OF CONVENIENCE, AND THE BONDS BETWEEN SOCIAL INSTITUTIONS
}

\begin{abstract}
In this study, we seek to pinpoint the tension between class society and colonizers in Brazil. The analysis is guided by showing how Machado de Assis unravels the demand that women marry within Brazilian nobility. The author sets the story on a backdrop of the political changes that took place during the nineteenth century that could influence the lives of the main characters. The view on love is unromanticized; sincere affection is seen as the reason for shame. Therefore, the aim is to show how the establishment of the bourgeois model in a patriarchal and slave society took place. From this association, we saw a solution that results in either the failure of the modern project, or its defect.
\end{abstract}

Keywords: Machado de Assis; money; marriage; nineteenth century.

Uma moça que professasse ideias filosóficas a respeito do amor e do casamento diria que os impulsos do coração estavam antes de tudo. Rosina não era inteiramente avessa aos impulsos do coração e à filosofia do amor; mas tinha ambição de figurar alguma cousa, morria por vestidos novos e espetáculos frequentes, gostava enfim de viver à luz pública. Tudo isso podia dar-lhe, com o tempo, o rapaz de nariz comprido, que ela antevia já na direção da casa em que trabalhava; o Ernesto porém era dificil que passasse do lugar que tinha no arsenal, e em todo o caso não subiria muito nem depressa.

[...]

As intenções de Rosina, leitor curioso, eram perfeitamente conjugais. Queria casar, e casar o melhor que pudesse. Para este fim aceitava a homenagem de todos os seus pretendentes, escolhendo lá consigo o que melhor correspondesse aos seus desejos, mas ainda assim sem desanimar os outros, porque o melhor deles podia falhar, e havia para ela uma cousa pior que casar mal, que era não casar absolutamente.

Machado de Assis, "Ernesto de tal" 


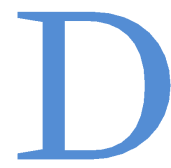

urante o século XIX, o Brasil precisou conviver com duas mentalidades a princípio antagônicas, mas que no nosso país serão talvez complementares, ainda que convivendo em tensão. Uma já vigente, de mentalidade conservadora e tradicional, que se correspondia, no plano econômico, à manutenção do regime de escravidão. Com a vigência desse quadro, os homens livres e pobres dependiam da política do favor e do apadrinhamento daqueles que tinham posses e influência social. Em uma sociedade que contava com trabalho escravo, os que tinham apenas a força de trabalho para oferecer ficavam à mercê da boa vontade das elites proprietárias. Esse quadro conservador garantido sobretudo pela escravidão se completava socialmente pelo patriarcalismo que destinava as mulheres ao lar e dificultava a inserção no mundo do trabalho. A outra mentalidade nascia pelas tentativas de introdução do país num mundo liberal e com um estágio de capitalismo mais avançado. Nesse novo contexto, os pobres contariam, ao menos idealmente, com possibilidades de ascensão através do mérito e as mulheres teriam que ser preparadas, ao menos para colaborar com a educação doméstica dos filhos e assim ajudar a formar mão de obra com alguma ilustração. Em meio a esse quadro de tensões, a possibilidade de ascensão social passa a contar, na hora em que as moças vão escolher seus futuros maridos. Ao mesmo tempo, para elas, casar é ainda a única via de acesso à consideração da sociedade.

$\mathrm{O}$ fragmento citado representa o senso de realidade de uma moça em meados do século XIX. Consciente da necessidade de realizar um casamento, ela é igualmente consciente da conveniência de fazê-lo com alguém que possa ascender socialmente e dessa forma suprir seus anseios de bens materiais e prestígio social. Como se vê, a moça em questão não tem aspirações românticas de um casamento por amor, e nem representa a fragilidade feminina que tantos poetas românticos retratavam como ideal. Entretanto, as mulheres não são as únicas que sofrem exigências sociais no Brasil oitocentista; aos homens de poucas posses também era indispensável conseguir meios para se manter e ascender social e economicamente. $\mathrm{O}$ fragmento citado abriga, entre outras coisas, o embate que se encenou no Brasil entre os valores do liberalismo nascente e as práticas de um mundo senhorial ainda sólido. Considerando essas tensões, é possível compreender melhor a competição entre Ernesto e o "rapaz de nariz comprido" pelo amor de Rosina. Enquanto o primeiro faz parte do exército - instituição pública que representava um lugar com garantia de sobrevivência e estabilidade em 
contexto senhorial -, o segundo representa a promessa de um mundo liberal e movido pelas leis da concorrência. Afinal, o "rapaz de nariz comprido" é um comerciante.

Publicado originalmente em 1873 no Jornal das Famílias e no mesmo ano relançado no livro Histórias da meia-noite, "Ernesto de tal" narra a intriga que culminou no casamento de Ernesto com a esperta Rosina. Ernesto havia brigado com a namorada, pois a surpreendera trocando bilhetes com um primo; depois disso prometeu nunca mais vê-la. No entanto, sem conseguir manter a promessa, envia um pedido de desculpas e aguarda a resposta que não chega porque Rosina estava entretida com outros rapazes presentes numa festa organizada por seu tio. A atenção da moça é especialmente voltada para o personagem que o narrador apresenta como "um moço de bigode louro e nariz comprido" (ASSIS, 1986, p. 206). Enquanto espera por resposta, Ernesto esconde-se na penumbra em frente da casa onde a festa ocorre. Embora houvesse sido convidado pelo tio da moça, o sr. Vieira, que havia organizado essa comemoração para algum acontecimento familiar, Ernesto não entra, devido a impossibilidades materiais. Afinal, o convite exigia que os homens portassem uma casaca. A imposição do traje existia porque um dos convidados da festa era o subdelegado e comendador. E esse é um ponto fundamental que evidencia a situação de carência financeira de Ernesto. Estando ele ausente, Rosina tem tempo e espaço para flertar com o moço de nariz comprido, que em tudo é mais galante e charmoso do que o seu namorado. A partir dessa festa, ambos - Ernesto e o rapaz do nariz comprido - passam a ser namorados de Rosina, sem que um saiba do outro. $\mathrm{O}$ rapaz de nariz comprido é autorizado a frequentar a casa da moça e surge a promessa de casamento, tão logo o rapaz consiga dinheiro para isso. Além disso, o tio de Rosina faz gosto na escolha da sobrinha, pois o rapaz é da área do comércio e, portanto, nele se deposita uma promessa de crescimento e de ascensão social. Ernesto ainda não sabe da trama, mas suspeita, já que a sua natureza é desconfiada e ciumenta. Quando não suporta mais a situação, é aconselhado por seu amigo Jorge a procurar o rival para que tudo fosse esclarecido. Ernesto vai ao escritório de contabilidade em que o rapaz de nariz comprido trabalha. Ali, eles acabam revelando um ao outro o procedimento de Rosina. Decidem que ambos romperiam com ela e enviam cartas de igual conteúdo, pondo fim aos respectivos compromissos. Ao perceber que fora desmascarada, Rosina chora de raiva, julgando-se "abandonada de Deus e dos homens" (ASSIS, 1986, p. 216). Pouco tempo 
depois, ela envia uma carta a Ernesto pedindo que a visite. Engana o apaixonado, dizendo que tudo aquilo não passou de um mal-entendido e jurando-lhe o seu amor. Ernesto então a perdoa, casam-se. O desfecho que Machado dá ao conto é, todavia, sintomático de sua posição quanto à tensão existente entre as forças do Brasil senhorial e o quadro de liberalismo nascente. Ernesto e o rapaz de nariz comprido viram sócios em um armarinho. Logo, o exército, força atuante no quadro conservador do Brasil escravista, entra em consórcio com os elementos que anunciavam uma nova ordem.

O conto pode nos ajudar a refletir sobre algumas mudanças ocorridas na sociedade oitocentista cuja turbulência se iniciou com a chegada da Família Real portuguesa ao Brasil em 1808. Apesar de escrito em 1873, a narrativa tem como pano de fundo a sociedade fluminense de 1850 , período marcado pela tentativa de inserção e estabelecimento de práticas liberais no Brasil. A década de 1850 do século XIX é a época do apogeu do Segundo Reinado, período de supressão das revoltas provinciais, quando se esfriavam as disputas políticas com a formação dos gabinetes e a conciliação dos partidos. Justamente em 1850, em 9 de setembro, é sancionada a Lei $\mathrm{n}^{\mathrm{O}} 581$ Lei Eusébio de Queirós - que extingue, oficialmente, o tráfico negreiro no Brasil, o que dificultou a possibilidade de compra de mão de obra escrava. A extinção do tráfico aconteceu após imensas pressões feitas pela Inglaterra, que já vinha apreendendo "navios negreiros". O Brasil, nessa época, era o país que mais recebia esse tipo de mão de obra, sendo que - de acordo com Schwarcz e Starling (2015) - do total de africanos transportados para a América, 83\% tinham como destino o Brasil, 12\% iam para Cuba, e o restante era dirigido para Porto Rico e Estados Unidos. O fim do tráfico acabou disponibilizando verba para a reestruturação interna do Brasil, pois, como esse comércio nem sempre era legal, não havia receita a ser recolhida pelo Estado. Até então, o governo recolhia, basicamente, apenas impostos de importação e, quase que de repente, viu-se com os cofres cheios que serviriam para implantar linhas férreas, construir as primeiras linhas de telégrafo e navegação, instalar iluminação a gás nas grandes cidades e criar estabelecimentos de ensino e instrução. No mesmo ano, no dia 18 de setembro, é sancionada outra lei, a $\mathrm{n}^{\mathrm{0}}$ 601, mais conhecida como Lei de Terras, que impossibilitava a posse ou doação de terra no território brasileiro para outrem. Ela "visava a organizar o país para o fim eventual do trabalho escravo" (SCHWARCZ; STARLING, 2015, p. 274) e tinha como objetivo 
transformar a terra em propriedade privada, o que gerou diversas implicações para o Brasil, como acumulação de terra na mão das elites agrárias, impossibilitando que pequenos produtores mantivessem a posse de suas terras, de onde tiravam a subsistência, e também dificultando a aquisição de terra por parte de futuros imigrantes, gerando uma grande concentração de terra nas mãos de poucos. Esses fatos possibilitaram a formação de uma oligarquia rural e, com isso, suas ligações e influências na política do país. Por conseguinte, o governo imperial pretendia, com a arrecadação sobre as taxas de registro e demarcação de terra, patrocinar a vinda de imigrantes - principalmente europeus e orientais - para disponibilizar mão de obra livre para as lavouras e substituir o trabalho escravo, pois, com o fim do mercado negreiro, era necessário recorrer ao mercado interno, que passou a custar mais caro; além disso, havia a ideia de "branquear" o país - posicionamento defendido por teorias científicas da época. Mas o Brasil não era o destino preferido dos imigrantes, também por causa da escravidão e por não haver condições favoráveis para que eles pudessem se manter aqui, como as doações de terra que aconteciam na América do Norte.

A década de 1850 também ficou muito conhecida pela prosperidade e estabilidade financeira. Parte disso se devia à alta do café nos mercados estrangeiros e ao aumento das vendas pelos produtores brasileiros. O período a partir do ano de 1854 e se estendendo até 1889 ficou conhecido como a Era Mauá, etapa de progresso financeiro que modernizaria a técnica de transporte e aperfeiçoaria os serviços urbanos, como iluminação, calçamento e saneamento - e modificaria o estilo de vida nas cidades.

De acordo com Sérgio Buarque de Holanda, nesse período, em que houve a proibição do tráfico de escravos, a nossa história comercial passou por uma transformação súbita sem precedentes. As importações subiram a um nível altíssimo e com isso "a ânsia de enriquecimento, favorecida pelas excessivas facilidades de crédito, contaminou logo todas as classes e foi uma das características notáveis desse período de 'prosperidade"'. Adverte ainda Buarque de Holanda que "o fato constituía singular novidade em terra onde a ideia de propriedade ainda estava intimamente vinculada à da posse de bens mais concretos, e ao mesmo tempo menos impessoais do que um bilhete de banco ou uma ação de companhia" (HOLANDA, 2004, p. 77). Em vista disso, essas medidas deveriam permitir que o Brasil saísse gradualmente do regime escravista, eliminando a comercialização de escravos vindos de fora - mas a 
história comprovará que o comércio negreiro acabou no Brasil, só oficialmente, em 1850, mas que ainda perduraria por mais alguns anos clandestinamente, com as "vistas grossas" que algumas autoridades fariam possibilitando o comércio ilegal. Em 1850, o Rio de Janeiro, como capital do Império, entrava em uma nova fase, com a associação da especulação financeira e os relacionamentos sociais - como apresenta Schwarz -, "tratase da entrada da forma mercadoria e de seus efeitos ideológicos - o fetichismo, que consiste em ver na mercadoria, não o efeito, mas as razões dos relacionamentos sociais, o que é contrário às relações paternalistas, que naturalmente se querem primeiras", deste modo, "para a vida cotidiana, sem que se transformasse a base escrava da economia". Havia contradição, mas não antagonismos essenciais entre o paternalismo e a introdução da mercadoria no cotidiano, pois ambos expressavam "formas de um mesmo poder, que aos poucos e sempre conforme a sua conveniência passava de uma para a outra, sem que a dissolução dos vínculos tradicionais tivesse caráter subversivo" (SCHWARZ, 2012, p. 164). Com isso, temos em termos históricos o que Machado representará na forma de tensão nas mentes e nas formas de convivência. Trata-se de uma prática liberal que, introduzida na política econômica, e também na prática do comércio e da especulação financeira com suas promessas de enriquecimento, convivia com as práticas tradicionais de prestação de favor e dependência, com as relações de compadrio e apadrinhamento conferindo poder aos que tinham dinheiro e influência.

Através de Schwarz vemos em que medida esse contexto histórico penetra as tramas criadas por Machado de Assis:

Segundo Gledson, mais que simples localizações no tempo, as datas apontam as questões históricas a que as peripécias ficcionais e a composição dos caracteres tomam emprestada a substância. No extremo, esta leitura transforma o romance em alegoria política. Sem chegar a tanto, veremos que as correspondências não faltam, injetando virtualidade alegórica nas personagens e buscando erguê-las acima da craveira irrelevante, ou doméstica, de seus conflitos. (SCHWARZ, 2000, p. 74)

Citando Gledson, cuja crítica caminha tensamente para a leitura do romance machadiano como alegoria da história, Schwarz indica um modo de ler que, enraizando os personagens em seu mundo, termine por levá-los até 
uma dimensão mais geral em forte correspondência com a história do país. Em acordo com essa proposta, o conto retirado de livro inicial de Machado terá aqui ressaltadas as correspondências eventualmente existentes entre o quadro ficcional e o contexto histórico, tal como esse contexto é interpretado pelo autor. Assim, os personagens principais do conto "Ernesto de tal" serão vistos como representações tanto dos impulsos de transformações presentes na sociedade brasileira do período como do modo tenso como essas transformações efetivamente eram operadas.

De início, o conto apresenta Ernesto, homem apaixonado que não pode ter sua identidade revelada. Por alguma razão, substitui-se o sobrenome, que seria seu elemento diferenciador, pela alcunha "de tal". Ele é um rapaz de índole ciumenta e desconfiada em relação à sua namorada Rosina, mas, ao mesmo tempo, Ernesto se manifesta como um homem "amador", que é capaz de abrir mão de qualquer orgulho para desposá-la. Alertado constantemente pelo amigo Jorge acerca do comportamento da moça, sempre acaba criando um pretexto para assegurar a inocência de Rosina e a sua pureza de caráter. Em verdade, ele sabe que está sendo enganado pela moça, mas faz tudo para que a sua conduta seja justificada. Quando confronta o rapaz de nariz comprido e ambos descobrem que estavam sendo enganados, ele é o único que posteriormente rompe o acordo de cavalheiros e se casa com a mulher que a ambos enganara. Seu nome é ocultado, como sinal de que há, na trama amorosa, aspecto negativo que, uma vez revelado, traria desprestígio. Não parece tratar-se da falta de dinheiro, já que a superação desse problema já é, no momento da escrita, um dado positivo. Pobre, Ernesto entrara no mundo do comércio, igualando-se ao antigo rival a quem se associara. Ao que tudo indica, sua falha é manter uma visão idealizada do amor que, vinda do Romantismo, cai em desuso num contexto em que tudo se torna especulação e interesse, e em que o casamento se efetiva como um negócio.

Rosina estava resoluta no objetivo de conseguir casar, independente de quem fosse o marido. Não casar era o que de pior poderia acontecer a uma mulher. Ao mesmo tempo, o sr. Vieira estava interessado em um sobrinhogenro que fosse a concretização das suas esperanças de inserção no novo mundo do capital. Assim, ele apoiava o casamento da sobrinha com o rapaz de nariz comprido. Este último, por sua vez, apesar de aparentemente gostar da moça, a abandona completamente, sem direito à defesa, e depois disso nunca mais se casa. Único capaz de ter uma afeição verdadeira, Ernesto tem o sobrenome ocultado, sendo assim preservado do rebaixamento. Seu nome, 
a propósito, significa "combatente firme que batalha até a morte" (DICIONÁRIO DOS NOMES PRÓPRIOS, on-line). Ernesto, realmente, luta até o fim para conseguir casar com Rosina, até o fim das esperanças e, do ponto de vista representado pelo amigo Jorge, até o fim da dignidade. Por isso, sua identidade precisa ser preservada. Ernesto é honesto em sua afeição e, além de representante da categoria dos homens pobres sem recursos e sem meios de ascensão, porque não faz parte de nenhuma ligação clientelista, também é representante do amor romântico que é capaz de superar qualquer empecilho. Pretende casar-se com Rosina por amor, a prática aceita pelo ideário romântico-burguês, ainda que, na prática social burguesa, o contrato nupcial fosse feito a partir do jogo de interesses. Ao contrário dele, o rapaz de nariz comprido não possui nome na narrativa, já que também não possui individualidade. Trata-se de um tipo, é o típico homem oitocentista com aspirações ao enriquecimento.

Ernesto possui um emprego público, pequeno e com possibilidades de crescimento quase nulas no exército. Na cena que abre o conto, ele está na penumbra do lado de fora da casa de Rosina, pois não pode entrar na festa oferecida pelo tio da moça. Lembramos que, tendo sido convidado, ele não possuía o traje obrigatório do evento, a casaca. O tio de Rosina, o sr. Vieira, estava dando a festa para comemorar algum pequeno acontecimento familiar que não é revelado no conto. Como já foi dito, a exigência da casaca para um evento tão íntimo dava-se pela presença ilustre do subdelegado e comendador. Trata-se, portanto, de sinal de clientelismo. Vieira tipifica o clientelismo que prevalecia no Brasil e esse tipo de reconhecimento por parte do favorecido transformava a prestação de favor numa "cerimônia de superioridade social" (SCHWARZ, 2012, p. 20). O tio de Rosina transforma uma reunião de família num pequeno evento social em homenagem ao subdelegado, sem que o aparente motivo seja explicitado no texto. Sabe-se que Vieira não era rico, conclui-se então que seja um daqueles homens livres do século XIX que possuem um emprego público alcançado por um favor de alguém influente. Provavelmente o subdelegado constituía uma fonte de favores, uma vez que o próprio título de "comendador" é indicativo dessa condição. Vieira representa o homem livre, que se insere na longa e hierárquica cadeia de apadrinhamentos. Como nos explica Schwarz, o apadrinhamento através do favor era a regra à qual os homens e as mulheres tinham que se submeter para poder sobreviver no país escravista. A dependência dos pobres aos caprichos das classes dominantes era a forma de 
sobrevivência que poderia alterar radicalmente o destino do dependente, resultado de um reconhecimento arbitrário e por vezes humilhante. Os homens livres e pobres estavam fora do quadro de elementos básicos de formação da sociedade nacional: os proprietários e os escravos. Para ter acesso aos bens da civilização, era necessário contar com a benevolência da classe abonada. Esse tipo de proteção é contrária à base ideológica-moral dos países em que já havia ocorrido a Revolução burguesa. O homem pobre livre, portanto, é o dependente que precisa direta ou indiretamente do favor, não podendo abrir mão de executar gestos subalternos; para esses homens, o "excesso" de orgulho próprio pode acarretar repulsa ou retaliação, além do inevitável desamparo. A caricatura desse homem se dá na figura do agregado. Uma das formas de se prestar esse favor era através da obtenção/nomeação a um cargo público. O sr. Vieira agradece o favor obtido de maneira pública, exigindo a casaca como símbolo de distinção pela honrosa presença do comendador.

Sérgio Buarque de Holanda nos alerta sobre a já preexistência da política do favor na sociedade portuguesa. A respeito disso, ele diz que comerciantes estrangeiros perceberam que, para conseguir fazer um negócio mais vantajoso com um português, era preciso, primeiro, fazer dele um amigo. Observou-se, também, a aquisição de vantagens entre povos ibéricos, que adotavam a prestação de favores a parentes e amigos em troca do exercício de sua função. Assim, eram concedidos descontos em passagens de trem, por exemplo, mesmo para pessoas ricas (HOLANDA, 2004, p. 133).

A estruturação da sociedade brasileira ocorreu devido à colonização e ao monopólio da terra que nos legou "três classes de população: o latifundiário, o escravo e o homem livre". Esse terceiro era dependente do primeiro para sobreviver, embora não estivesse sob o regime de exploração. "O favor é, portanto, o mecanismo através do qual se reproduz uma das grandes classes da sociedade, envolvendo também outra, a dos que têm". Os profissionais liberais também eram governados pelos latifundiários ou homens de posse.

O favor é nossa mediação universal - e sendo mais simpático do que o nexo escravista, a outra relação que a colônia nos legara, é compreensível que os escritores tenham baseado nele a interpretação do Brasil, involuntariamente disfarçando a violência, que sempre reinou na esfera da produção. (SCHWARZ, 2012, p. 16-17) 
Em contrapartida a essa mentalidade tradicional, o rapaz de nariz comprido é o representante do novo homem e da prática liberal, arauto de uma nova forma econômica em que todos apostavam na promessa de crescimento, enriquecimento e inserção do mundo moderno burguês, cujos costumes eram tão imitados pelas classes altas do país. Homem do comércio, do capital cujas formas pressionavam a velha ordem desde o advento das leis de 1850, "o rapaz de nariz comprido" é o provável marido de preferência de Rosina e do tio dela, surgindo para destruir as pretensões de Ernesto - apesar dos outros namorados de passatempo. Por isso, é interessante notar que o narrador nos indica que os fatos narrados no conto se passam em outubro de 1850 e a Lei Eusébio de Queirós e a Lei de Terras foram sancionadas em setembro do mesmo ano. Ou seja, logo após essas duas datas históricas que tinham como objetivo abrir espaço para a modificação social, cultural e ideológica do Brasil, aparece o moço de nariz comprido "metendo o nariz" na "história de amor", na relação de Rosina e Ernesto - um homem pobre e livre que, em contraposição à ideia do self-made man, não tem possibilidade de crescer no emprego que ocupa, sem a graça e simpatia de alguém influente da classe rica. No entanto, como vimos, no Brasil, as duas forças irão se associar e terminarão por nada contestar no que disser respeito aos rastros da ordem senhorial.

Compreensível que, dentro desse quadro de modernidade ainda insinuante no que tange às camadas mais visíveis da estrutura, o rapaz de nariz comprido pareça mais atraente e charmoso que Ernesto: "nem havia ninguém, pelo menos, naquelas imediações, que tivesse mais elegância na maneira de arquear os braços, de concertar os cabelos, ou simplesmente de oferecer uma xícara de chá" (ASSIS, 1986, p. 207). A prática liberal parecia elegante, com as suas promessas de enriquecimento e inserção no universo do capital.

No final do conto, as expectativas de casamento entre Rosina e o rapaz de nariz comprido acabam fracassadas; ela casa com o seu pretendente anterior. Na lógica da moça, "Quem não tem cão, caça com gato, diz o provérbio. Ernesto era pois, [...], uma espécie de pis-aller, - como dizem os franceses, - que convinha ter à mão" (ASSIS, 1986, p. 211). Ernesto de Tal e o rapaz de nariz comprido se tornam sócios, os acontecimentos desmentem as desigualdades e expectativas postas sobre eles. O desenvolvimento comercial que se insinuava através da figura do rapaz de nariz comprido foi frustrado. $\mathrm{O}$ obstáculo da impossibilidade da prática liberal, junto à impossibilidade de 
liberalização da dependência, foi realocado. Há realmente possibilidade de considerar um viés alegórico, pelo qual Machado atestaria que as promessas de inserção do Brasil no mundo moderno haviam naufragado. Aqui, as ideias burguesas de universalidade dos princípios e prática liberal estavam sendo aplicadas fora de seu contexto, ou fora de um contexto que as permitisse frutificar. A coexistência entre as duas formas poderia ser utilizada como justificativa para o arbítrio pessoal e para a "natureza do favor". Teoricamente, assumiam-se as "ideias mais ilustres do tempo", ou seja, a europeia do liberalismo e autonomia da pessoa. No entanto, a prática era outra e o que imperava era a relação de favor e conspiração. "Neste contexto, portanto, as ideologias não descrevem sequer falsamente a realidade [...] Assim, com método, atribui-se independência à dependência, utilidade ao capricho, universalidade às exceções, mérito ao parentesco, igualdade ao privilégio etc.". Dessa forma, "o antagonismo se desfaz em fumaça e os incompatíveis saem de mãos dadas" (SCHWARZ, 2012, p. 18-19). O consórcio entre os dois rapazes que se tornaram sócios de um armarinho é esse "sair de mãos dadas" entre o liberalismo - o capitalista que deveria crescer - e o funcionário acomodado no arsenal do exército que não possuía maiores expectativas.

Roberto Schwarz, em Ao vencedor as batatas, discute sobre como ocorreu essa convivência entre a universalidade dos princípios, de um lado, e as práticas gerais do favor e da escravidão. Sobre isso, ele diz que a liberdade de trabalho, igualdade perante a lei e o universalismo eram ideias completamente falsas no Brasil. Assim como na Europa havia o encobrimento da exploração do trabalho, no Brasil, a declaração dos direitos do homem que estava presente, em parte na nossa constituição, tornava a realidade brasileira e a escravidão ainda mais infames. O maior exemplo disso, dentro das práticas de mercado, era ter a escravidão como a relação produtiva fundamental, o que indicava impropriedade das ideias liberais - no entanto, não era o "nexo efetivo da vida ideológica". Esse nexo estava na relação de favor, da qual dependia o "homem livre" e sem posses que envolvia a classe dos homens de posse. Esse mecanismo social regerá a vida ideológica do país, mecanismo este que será utilizado por nossos escritores e que será usado também para tentar disfarçar a violência presente na esfera de produção. Portanto, no Brasil, as ideias burguesas seriam um ornato, uma marca de fidalguia, postas numa esfera augusta que, em nosso caso, é a 
Europa que já estava se industrializando. De lá vinham as ideias que eram aqui utilizadas fora de seu contexto e ganhavam status de comenda.

Por outro lado, Gilberto Freyre fala sobre como era a convivência dessa nova classe de burgueses negociantes que ansiava por dominar e pretendia quebrar o domínio e a exclusividade dos senhores de engenho sobre a vida pública. Depois de enriquecidos, esses negociantes se tornavam donos de terra, mas os senhores de engenho os confundiam, com puro desdém, com simples mascates. Os homens bem-sucedidos no comércio tendiam a imitar os senhores rurais, compravam terra e plantavam cana e café e, muitas vezes, para crescer na consideração social, se casavam com as filhas de senhores de engenho. "O casamento foi o meio de vários desses triunfadores, de origem burguesa ou plebeia, se elevarem socialmente até a classe rural, ao hábito de Cristo, ao título de sargento-mor ou capitão nos tempos coloniais, ao de barão ou visconde no Império" (FREYRE, 2004, p. 113). Outras vezes, esses casamentos eram realizados como forma de quitação de endividamentos de empréstimos que os senhores de terra faziam com esses "novos-ricos". Os pagamentos dessas dívidas eram realizados através dos arranjos de casamento entre filhos e filhas dos senhores de engenho com filhos e filhas desses negociantes, quando não com os próprios negociantes. Holanda explica que, com essa prática, tornava-se difícil distinguir os senhores dos sobrados (ou burgueses) dos senhores de engenho. Ambos, com isso, tornavam-se a mesma coisa.

Ainda seguindo as ideias de Schwarz (2012, p. 12), é preciso lembrar que o Brasil estava em descompasso com outros países, pois que era considerado "impolítico e abominável", onde ainda prevalecia a servidão um modelo "antagônico" ao liberalismo europeu. Eram muitas as disparidades entre o liberalismo e a sociedade brasileira que, por sua vez, usava essa base ideológica para encobrir a exploração do trabalho escravo. Assim, trazíamos ideias de fora para serem "implantadas" em ambiente hostil. Um traço disso é que, ao contrário do processo produtivo moderno, no regime escravista brasileiro, procurava-se aumentar o tempo de produção para ocupar e disciplinar o escravo, além de não haver nenhum tipo de especialização, ainda que a manutenção de um escravo fosse mais cara do que a de um trabalhador assalariado. Esse estado de coisas penetrou na ficção, sendo exemplarmente absorvido pela obra machadiana.

De todo modo, Sérgio Buarque de Holanda comenta como, com o fim do tráfico negreiro e o surgimento do mercado especulativo, dois mundos 
distintos começaram a se estranhar e se opor. Um resultante do que era o tradicionalismo do Brasil rural e patriarcal, e outro, liberal cosmopolita. "Eram dois mundos distintos que se hostilizavam com rancor crescente, duas mentalidades que se opunham como o racional se opõe ao tradicional, ao abstrato, o corpóreo e o sensível, o citadino e cosmopolita ao regional ou paroquial", e segue dizendo que a crise entre esses dois mundos "foi o desfecho normal de uma situação rigorosamente insustentável nascida da ambição de vestir um país ainda preso à economia escravocrata com os trajes modernos de uma grande democracia burguesa" (HOLANDA, 2004, p. 7879). Pois que as leis de 1850 eram a tentativa de colocar o Brasil na gama das civilizações modernas.

A respeito do estabelecimento da burguesia no Brasil, Florestan Fernandes discorre sobre as impropriedades da lógica capitalista por nós imitada. Ao contrário de outros países em que a classe burguesa criava instituições próprias de poder social, a classe burguesa brasileira converge sempre para o Estado e impõe seu poder, desde o início, sobre o poder político. Dessa forma, a burguesia nacional buscará continuamente influenciar o Estado e desenvolver pressões, controlando a política, a fim de conseguir seus objetivos particulares. Assim, o poder das oligarquias latifundiárias, de fato, não acabaria, e nem o seu mundo de favores. As várias ilhas que se formaram em torno das plantações se justapõem e confluem no comércio por terem interesses em comum. Toda essa movimentação não provocou profundas transformações no cenário social. Longe de assumir o papel de "paladina da civilização" ou "instrumento da modernidade", a burguesia brasileira vai tirar proveito de toda e qualquer situação para benefício próprio. "A modernização caminha rapidamente, pelo menos nas zonas em expansão econômica e nas cidades mais importantes em crescimento tumultuoso; e sua ansiedade política ia mais na direção de amortecer a mudança social espontânea, do que, no rumo oposto de aprofundá-la". A oligarquia latifundiária vinha e vivia em um "estrito mundo provinciano", fosse na zona urbana ou na zona rural. Vivia num estranho conservadorismo sociocultural e político, assim como a burguesia; apesar de se opor às oligarquias, reproduzia os mesmos preconceitos e mandonismos. O conflito entre burguesia e oligarquia latifundiária emergia de discórdias vinculadas a interesses materiais "ditados pela necessidade de expandir os negócios". Dessa forma, a ordem burguesa se travestia de revolucionária, democrática e nacionalista e propunha, inclusive, "o modelo francês da 
revolução burguesa nacional e democrática". No entanto, as representações do ideal da vida burguesa só valiam para ela mesma, enquanto que mais de $3 / 4$ da população estava de fora dessa realidade e, aos que tentavam reivindicar a inserção nesse circuito fechado, a burguesia nacional irá sempre mostrar a sua verdadeira face conservadora, reproduzindo "o melhor da tradição do mandonismo oligárquico" com grande repressão. Consequentemente, revolução burguesa, em sua acepção, seria algo irreversível de maturidade e que consolidaria o poder e a dominação burguesa. No Brasil, o que é chamado de revolução é apenas o seu gérmen, o que ainda é denominado de colapso nas oligarquias é uma transição que inaugura "uma recomposição das estruturas do poder", ainda sob a hegemonia oligárquica. Essa reposição marca o início da era moderna no Brasil (FERNANDES, 2007, p. 268).

Perdido nesse mundo de "ideias fora do lugar", que apenas se anunciava em 1850, está Ernesto com o seu "dilema da casaca". Ele possuía um emprego no arsenal de guerra que não lhe rendia o suficiente para ter qualquer tipo de prestígio social, o caso da casaca simboliza a sua precariedade e a sua exclusão do ambiente de homens mais favorecidos de poder e influência. A ausência da casaca marca a total impossibilidade de inclusão de Ernesto no círculo de poder, mesmo que nesse círculo convivam as promessas do liberalismo e as práticas do favor.

Stallybrass recorre a Engels para comentar a função do vestuário como distinção social. "As roupas, escreveu Engels, eram as marcas visíveis da classe", através delas, é possível perceber a qual estrato social o indivíduo pertence. Nesse caso, saber se a pessoa pertence à classe aristocrática/burguesa ou se é apenas um trabalhador livre mal remediado. Assim, ela serve como moeda de incorporação. Na Inglaterra renascentista, por exemplo "ser membro de uma casa aristocrática, ser membro de um guilda significava vestir-se de libré, significava ser pago, sobretudo em roupas. E quando um membro de uma guilda tornava-se livre, dizia-se dele, ou mais raramente dela, que tinha se 'vestido'". Portanto, para Ernesto, ir ao baile sem a casaca seria uma denúncia do seu lugar social. Suas possibilidades de ascensão através do casamento estavam prejudicadas, já que se apaixonara por Rosina, também ela necessitada de ascensão. Somente o rapaz de nariz comprido contava com a possibilidade de melhoria pelo trabalho, planejando "ajeitar" sua situação financeira para poder se casar.

Outro destaque para o valor o vestuário na sociedade, longe da necessidade imperativa das mudanças da moda, está no caso de Marx em 
1850, que, devido às difíceis condições financeiras pelas quais passava quando estava escrevendo $O 18$ de brumário de Luís Bonaparte, teve a necessidade de deixar de ir à biblioteca fazer sua pesquisa, pois estava com dívidas com o açougueiro e o verdureiro. Como tinha que sustentar uma casa com quatro crianças e três adultos, precisou penhorar seu casaco de inverno. Mesmo tendo um passe para frequentar o Museu Britânico, não podia fazêlo, pois a instituição não permitia que qualquer um entrasse; e "sem seu casaco Marx não estava, em uma expressão cuja força é difícil de reproduzir, vestido em condições em que pudesse ser visto" (STALLYBRASS, 2008, p. 4748).

Gilda de Mello e Souza, em seu $O$ espírito das roupas, fala sobre a relação da moda e as transformações ocorridas na sociedade, sobre a importância da vestimenta na sociedade e a importância do traje como reflexo das modificações dos costumes, e a relevância da moda como forma de ostentação da condição do indivíduo. Dentro desse enquadramento da sociedade urbana, o indivíduo passa a ser aquilo que veste, a roupa masculina é utilizada como um instrumento de afirmação pessoal. A partir da Revolução Francesa há a mudança da sociedade estamental para a sociedade de classes, "a carreira estava aberta ao talento [...] Nesta nova aristocracia que se forma, 'tríplice aristocracia do dinheiro, do poder e do talento"' (SOUZA, 1987, p. 81), a burguesia traça um novo estilo de vida que é seguido por todas as camadas. Nesse processo, o que outrora era "apanágio das elites" ganhou uma nova significação com as carreiras e profissões liberais. O homem ganha um novo jeito de trajar, mais elegante e prático. O traje passa então a ser uma distinção social, uma espécie de segunda pele. A industrialização e a produção em larga escala ainda farão com que as classes menos favorecidas procurem imitar o padrão de vestimenta das classes mais altas, mas "a vestimenta está sempre em evidência e oferece, à primeira vista, a todos os observadores uma indicação de nosso padrão pecuniário" (SOUZA, 1987, p. 124). Com o advento da burguesia e da industrialização, surge um novo estilo de vida e a casaca será a vestimenta dos capitalistas e banqueiros ingleses, e, apesar de pouco usual, como sugere o conto, a casaca tem a marca simbólica do mundo moderno e do homem burguês.

Ao tratar de realidade periférica em que há uma complexa estrutura de desigualdades sociais e de difícil transposição, Nikolai Gógol narra, em $O$ Capote, a história do funcionário público Akaki Akakiévitch, que, por ganhar pouco, não consegue comprar um casaco novo; o único que tem é tão velho e 
gasto que é chamado pelos colegas de repartição de "capote", um termo pejorativo. Quando ele tenta fazer um novo remendo no capote, descobre que isso não é mais possível e que terá de mandar fazer um novo. Depois de alguns sacrifícios, Akaki consegue seu casaco novo, o que chama muita atenção na repartição onde trabalha e se torna motivo de comemoração oferecida pelo subsecretário em sua casa. Saindo da festa, Akaki é assaltado e perde seu novo casaco. Akaki, até então, não contava com o respeito e nem a consideração de nenhum dos colegas, ao contrário, ele era motivo de piada entre todos. Sua vida se resumia em ir ao trabalho e voltar para casa, depois de copiar documentos da repartição. Akaki é copista de documentos do ministério e desse cargo não consegue ascender, pois não tem capacidade para fazer um trabalho um pouco mais complexo. O capote gasto de Akaki é o símbolo, na narrativa, de seu locus social miserável e não pertencimento. Quando compra o capote novo, ele passa a ser notado e, de alguma forma, respeitado; e até a ser convidado para confraternizar com os outros. Mas aquele é apenas um meio artificial de status, pois que Akaki é roubado na noite da comemoração oferecida pelo subsecretário e volta a ser aquele velho de sempre, contando, talvez agora, com um pouco da comiseração de seus colegas. Na Rússia do século XIX, a vestimenta é um símbolo da casta social, a exemplo da mulher do costureiro de Akaki, Petrovitch. Sobre ela não se sabia muito a não ser que "usava uma touca no lugar de um xale". Esse simples detalhe já era o suficiente para distinguir as mulheres do povo, que usavam xale, e as pequeno-burguesas, que usavam touca. Acontece que Petrovitch era um servo alforriado. O final trágico de Akaki é, também, a representação da impossibilidade de modificação de sua situação; o que, no conto de Machado, será aludido pelos três enterros que Ernesto encontra durante a sua busca pela casaca (GÓGOL, 2000).

A casaca, então, era só utilizada em momentos muito solenes, e o pedido de Vieira era uma extravagância; ele também não era rico, apesar de gozar de mais posses e relações do que Ernesto. A imposição do uso da casaca em uma festa que tinha como objetivo solenizar um pequeno acontecimento familiar tem, na trama, significado ambíguo. Realizada para celebrar o pacto do favor, a festa exige um sinal de distinção vindo da Inglaterra e associável aos banqueiros e ao capitalismo inglês. Ernesto será excluído, por causa da casaca, e procura em vão por um amigo que lhe empreste um traje, já que não tinha condições de comprar um (nem a crédito). Não consegue, esgotam-selhe as possibilidades e, por movimento irônico do destino, em seu caminho 
de volta, abatido nas esperanças, ele se depara com dois enterros nos quais os ocupantes dos carros iam todos de casaca. Era, pois, a morte das esperanças de Ernesto de entrar na festa em que as formas modernas se associavam às práticas do favor. Sem dinheiro e sem relações sociais capazes de conduzi-lo à posse da casaca, era ele o homem livre sem patrimônio e sem padrinhos.

Em outro aspecto, no sentido de transformação e mudança, o conto também sinaliza para a modificação do arranjo matrimonial para as mulheres. Antes sem autonomia, passam a interferir mais vivamente na definição dos seus parceiros. Rosina marca, então, a transformação do jogo do arranjo matrimonial, principalmente, porque o Brasil era um país recémsaído do domínio da metrópole que tentava afirmar-se diante dos países que já haviam ingressado na modernidade. Poucas décadas antes, os brasileiros das classes altas ainda possuíam o hábito de manter as mulheres reclusas. Em meados do século XIX, começa a surgir um novo tipo de mulher na sociedade que foi substituindo aquele modelo servil e ignorante. A mulher passou, então, a frequentar mais a rua, os bailes, teatros e cafés. Passa a receber mais instrução, lê romance e vai frequentando menos os confessionários.

$\mathrm{Na}$ primeira metade do século XIX, havia grande isolamento das mulheres - até mesmo nas zonas urbanas e de classe média -, tanto que, quando havia visitantes em casa, elas se retiravam e só participavam da reunião se entre o grupo visitante houvesse alguma senhora. Nesse Brasil, restavam às mulheres poucos divertimentos, pois via de regra não podiam caminhar livremente nas ruas, não podiam entrar em contato com estrangeiros e estranhos e não tinham educação formal. Também não era comum a frequência de bailes para que as pessoas mantivessem contato ou se conhecessem, como ocorria na Inglaterra. Nesse ambiente, as ideias que contribuíram para a cristalização dessa posição feminina vinham da Igreja Católica. A mulher, na visão da Igreja, deveria estar subordinada ao homem. Obediência e servidão são formas de manutenção "dos bons costumes e da ordem". Por isso, com essa diferenciação entre os sexos - o que permitia ao homem ter todas as liberdades e o gozo físico do amor -, à mulher era concedido ser obediente aos desejos do homem, conceber e cuidar das crianças. Esse "padrão duplo de moralidade" também dava aos homens oportunidade de iniciativas e ação social; as mulheres deviam lidar com a família, parentes, escravos e o confessor. Porquanto, segundo Ingrid Stein, as correntes de pensamento afinadas com o positivismo defendiam a 
continuidade dessas ideias. Nessa doutrina, a família é uma das instituições fundamentais da sociedade e a mulher, como sustentáculo da sociedade moderna, só pode se dedicar excepcionalmente às atividades intelectuais destinadas ao homem. Da mesma forma, o higienismo - doutrina que surge no início do século XIX, tendo como base o positivismo - estabelece diretrizes da medicina social para a família. Essas diretrizes buscavam a "europeização" dos costumes e aceitam, sem fundamentação, a suposta inferioridade feminina. Segundo elas "o casamento é para a mulher a 'precisão da união' e para o homem 'desejo de gozo'; 'o amor [...] é no homem a necessidade dos sentidos e na mulher a do coração'" (STEIN, 1984, p. 4243). Nessa posição conservadora e antiemancipatória dos positivistas, a mulher era considerada um ser sem individualidade própria que guiava sua vida pelos outros: família, pais, marido e filhos.

Com a tentativa de europeização por diversos setores da sociedade, temos como contraponto a sociedade inglesa, com a redefinição dos papéis sociais devido às novas formas tomadas na sociedade com a Revolução Industrial. As famílias burguesas passaram a viver em locais afastados no subúrbio, longe da movimentação das indústrias. Isso colocou a mulher burguesa em uma situação mais reclusa e afastada de um trabalho fora de casa. A mulher passou, então, a ser criada para constituir família, e longe desse lugar seria acusada de não obedecer a sua condição "natural". Por conseguinte, aos homens cabia o papel político, nas empresas e de prover a família. "Os cuidados com a família deveriam, portanto, ser assumidos como uma vocação e o trabalho doméstico como uma profissão. Às mulheres foram conferidas qualidades altruístas: devoção aos outros, fortaleza moral, afetividade, delicadeza, sensibilidade." Dessa forma "o lar vitoriano passou a simbolizar estabilidade, paz e ordem, isto é o contrapeso às incertezas do mercado, sendo a dona de casa a fiadora desse paraíso, seu ponto de equilíbrio" (STEIN, 1984, p. 46-47).

Outra indicação da diferenciação entre os sexos que era promovida pelas instituições sociais era o grande contraste na educação feminina e masculina. Os pais escolhiam as profissões dos rapazes e os maridos das filhas. Essa realidade vem, no Brasil, desde o período colonial, em que os jesuítas negligenciavam a educação feminina e davam às mulheres apenas noções morais e religiosas. Ainda durante o século XIX, nota-se a disparidade entre os currículos das escolas para meninos e dos colégios para meninas. Elas aprendiam a ler, escrever, cantar, dançar, música, trabalhos 
com tesoura, além do francês. Eles, em contrapartida, aprendiam a ler, escrever, contar, geometria, aritmética, geografia e línguas, além de contarem com mais anos de estudo. Com esse currículo, as mulheres têm quase nenhuma opção profissional; pelas vias consideradas dignas para a época, as únicas opções aceitáveis são tornar-se preceptora ou exercer o magistério primário, ofícios aceitos por seu caráter maternal. Com isso, apenas em 1881 uma mulher conseguiu ingressar num curso superior na Faculdade de Medicina do Rio de Janeiro. E sendo a mulher casada, perante a lei, o marido era a cabeça da união e a mulher só poderia exercer uma profissão caso tivesse a autorização dele. Da mesma forma, o marido era quem deveria ter a administração da família e o poder de escolher onde deveriam morar. A mulher só assumiria o comando da família após a morte deste e, caso tivessem filhos, o pai e o avô da criança morressem e deixassem em testamento outro tutor para o filho, a mãe não teria direitos sobre ele.

No Brasil, o que ajudou a modificar a situação de reclusão das mulheres foi a chegada da família real portuguesa, marco para a transformação e importação de costumes, dentre eles, a criação de importantes teatros, como o de São João e o Lírico Fluminense, onde eram encenadas importantes peças e óperas nacionais e internacionais, locais que as pessoas frequentavam menos para louvar a arte e mais para poder "verem e serem vistas". Essas novas oportunidades de os maridos exibirem seu poder econômico através das roupas e joias das esposas era também oportunidade para as moças serem exibidas a futuros pretendentes. Outro hábito adquirido com a vinda da corte para o Brasil e que ajudou as moças a terem mais oportunidades de conhecer e escolher prováveis futuros maridos sem a imposição direta dos pais foi a prática de se promoverem saraus e bailes. "Os bailes conheceram seu momento de apogeu nesse contexto, adquirindo uma feição não só social como política, sendo o local para polêmicos debates entre partidos". Além disso, "lá se desenvolvia a arte de entreter uma palestra, cultivar humor, dançar uma valsa, cantar uma ária, declamar ou inspirar um verso, criticar com maledicência ou com piedade, cortejar as mulheres" (SCHWARCZ; STARLING, 2015, p. 278). Os saraus eram oportunidades para namoros, no entanto, tudo precisava ser feito com muito decoro, o papel da moça devia ser passivo e parecer desinteressado para aumentar o interesse do parceiro, cabia ao homem procurar aproximar-se e comunicar-se através de olhares e palavras. Segundo Thales de Azevedo, o flerte exercitado em recepções, saraus e bailes foi crescendo entre as classes média e alta brasileira a partir 
do século XIX. Antes, o flerte entre as moças e os rapazes se reduzia a jogos furtivos de leques, lenços e chapéus, e as brasileiras ficavam escandalizadas em saber que em países como a Inglaterra as jovens tinham a permissão para saírem desacompanhadas com os seus namorados. Aqui, as formas de namoro eram reguladas pela moral e nas classes altas não era permitido que rapazes e moças ficassem sozinhos sem a presença de, pelo menos, uma terceira pessoa.

Rosina era vista como uma moça "loureira", aquela que, na festa, ficava "requebrando de quando em quando os olhos", olhos que "não enganam ninguém... exceto os namorados. Os olhos dela são espertinhos e caçadores, e com um certo movimento que ela lhes dá, ficam ainda mais caçadores e espertinhos" (ASSIS, 1986, p. 205-206). Em outra cena de "Ernesto de tal", a tia de Rosina precisa se ausentar para verificar os serviços na cozinha e, como Ernesto estava de visita, ela chama o filho mais novo para que os dois não fiquem sozinhos. É verdade que o menino parece não prestar muita atenção ao que os dois conversam, mas é importante, para a moral familiar, que ele atue como vigia. Ao mesmo tempo, a tia parece se ausentar propositalmente para que os namorados possam conversar a sós. Tanta vigília era feita no intuito de que as moças das classes mais favorecidas não tivessem experiência sexual antes do casamento, por isso os homens se relacionavam principalmente com prostitutas ou com moças das camadas mais pobres, como empregadas ou escravas - o que poderia acarretar em uma gravidez comprometedora. O namoro assim, era realizado às escondidas, por meio de bilhetes, nos jardins ou por cima dos muros (quando era possível), e podia se estender por meses ou até anos, até que o namorado tivesse condições econômicas para pedir a mão da escolhida.

Além disso, ainda de acordo com Thales de Azevedo, para que um casamento fosse bom, era preciso que o marido tivesse condições de sustentar a si e à família, sem que a mulher precisasse trabalhar fora. Os rapazes esperavam ter boas condições ou expectativas de uma boa condição para pedir uma moça em noivado: "o propósito de casar-se, cultivado nos namoros sérios, é um estímulo ao esforço por ganhar a vida, conseguir um emprego fixo, amealhar economias" (AZEVEDO, 1986, p. 80). Vê-se que, se isso já é verdade no que concerne ao rapaz do nariz comprido, ainda não o é para Ernesto, cuja posição social parece sem grandes chances de mutabilidade, em que pese a hierarquia interna da carreira militar. Somente no caso do rapaz de nariz comprido a consolidação de um bom estado 
econômico exigiria prolongamento do namoro. Algumas moças até se sentiam prejudicadas quando o namorado demorava por consolidar um compromisso por tempo muito prolongado. Isso talvez justifique o fato de que Ernesto não tenha sido imediatamente eliminado. Afinal, o pior para Rosina seria não casar.

[...] a preocupação em poder "tornar feliz" a amada corresponde à ideia muito corrente de que no casamento a moça deve encontrar um estado, por vezes um "estadão", que nas classes altas lhe assegure os privilégios da que [sic] Veblem chama de "classe ociosa". Não trabalhar para ganhar a vida, sobretudo fora do lar, ter empregadas domésticas, dispor do suficiente para uma existência cômoda, sem preocupações financeiras prementes, e ter em mãos algum dinheiro "para os alfinetes", quer dizer, para suas pequenas despesas pessoais. A moça casada espera esse suporte econômico para seu novo status, de maneira que o candidato ao casamento deve assegurar à sua escolhida a expectativa de condições de existência pelo menos idênticas às que ela tem na casa de seus pais. No Brasil, como noutras sociedades, essa questão é de crucial importância para a mulher, "porque o seu nível futuro é determinado, principalmente, pela realização do homem com quem ela venha casarse, em um futuro emprego, mais do que pela posição social da família dele. Mesmo que ela seja rica, espera-se que se saia bem em seu novo emprego; o fracasso, ainda que não implique em uma quebra do padrão de vida provoca uma perda de estima". (GOODIE,' apud AZEVEDO, 1986, p. 82)

O noivado era, então, o período de ajustes e entendimentos entre os nubentes e suas famílias, que antecede ao casamento, quando se faz a "corte". "A observação, contudo, mostra que a escolha de cônjuges processa-se pelo menos em duas etapas, uma que é verbalizada como o 'namoro' e outra que constitui o noivado propriamente dito ou 'noivado oficial'" (AZEVEDO, 1986, p. 5). Ou seja:

[...] o namoro à antiga é um padrão relativamente uniforme e rígido que serve a um projeto de família isogâmica realizado em fases bem definidas de seleção e de inter-relacionamentos dos candidatos ao casamento. Nesse esquema o namoro é, do ponto de vista moral, essencialmente um meio, embora com funções próprias enquanto

${ }^{1}$ GOODIIE, William J. A família. Trad. A. A. Arantes Neto. São Paulo: Pioneira, 1970. 
prefigura e antecipa satisfações da futura vida conjugal. Os critérios familistas e de classe que lhe servem de norma pretendem produzir manutenção do status dos parceiros com o máximo de integração psicológica dos cônjuges e de estabilidade da sociedade familial. Com as mudanças experimentadas pela família em sua estrutura e organização, pela urbanização e pela crise de cultura, os padrões de enamoramento se tornam mais flexíveis e oferecem alternativas, entre as quais persiste, nos meios mais conservadores, o namoro tradicional. (AZEVEDO, 1986, p. 96)

O rapaz de nariz comprido esperava ter essa condição - que não tardaria - para formalizar seu compromisso com Rosina e casar. Ernesto não possuía expectativas de ascensão.

Rosina, assim como outras moças da corte na segunda metade do século XIX, goza de alguma "liberdade", porque os pretendentes são frequentadores da casa, amigos ou convidados do tio. Ela mantinha Ernesto sob o seu controle com cartas e promessas, sem que se assumisse intenção oficial de casamento, quer dizer, sem que a família fosse informada sobre o relacionamento, o que não indica que os tios não soubessem do que acontecia. Do mesmo modo, a moça se correspondia e era visitada pelo rapaz de nariz comprido, esse já possuía uma sinalização de casamento, houve até uma comunicação informal das intenções ao tio, porque ele mesmo já via o rapaz como um futuro membro da família. Afinal, Rosina via nele o candidato que procurava e que atenderia melhor os seus anseios.

Mas a promessa de casamento se vê frustrada. Constatando a situação inesperada de ter sido descoberta e de haver perdido os dois pretendentes, Rosina sente-se "abandonada de Deus e dos homens" (ASSIS, 1986, p. 216). Afinal, no período oitocentista, uma mulher ser dispensada de um compromisso era humilhante e a diminuía diante da família e da sociedade, pois que

A dignidade da mulher exige, de acordo com o código que lhe requer altivez e sobranceria na defesa de sua honra, que a ruptura do namoro seja da sua iniciativa, sob pena de ficar diminuída e humilhada em seu círculo de parentela e de amizades; a ela compete evitar ou fingir que recusa a reconciliação sem provas cabais de arrependimento, devolver os presentes recebidos do namorado e exigir deste a devolução de suas cartas, retratos e outras evidências do compromisso que se rompeu. A reconciliação depende de satisfações às vezes humilhantes, de mostras 
irrefutáveis e mudança de conduta. Isto é tanto mais imperativo quanto maior o envolvimento atingido e tornado público. (AZEVEDO, 1986, p. 74-75)

Considerada a existência desse código, Rosina é instada a agir. Machado traz à tona esse código do namoro à antiga e mostra a sua realidade de aparência. Uma vez dispensada pelos cavalheiros, Rosina age; da mesma forma como ela não é jamais passiva, no que diz respeito ao momento da corte. Vivendo com a família do tio, que não é rico, não se veste com luxo, mas é elegante e por sua condição não se espera que tenha um grande dote, se tiver algum. Da mesma forma, fisicamente, ela está longe do ideal romântico da mulher lânguida e melancólica. Possui senso muito prático e racional. Por força do cálculo, Rosina pretere Ernesto em favor do rapaz de nariz comprido. Essa capacidade de calcular faz de Rosina um prenúncio de duas famosas personagens machadianas: Iaiá Garcia e Capitu. A primeira conjuga instinto e interesse de ascensão social; a segunda, envolta em espessa ambiguidade, é, sem dúvida, dotada do poder de simulação e da capacidade de conseguir os seus objetivos. Com plena consciência de quem era e de quais eram as suas possibilidades, Rosina jogava com as cartas que tinha e com os pretendentes disponíveis em seu círculo social.

Rosina tentava escapar ao destino das mulheres que não conseguiam casamento algum, pois na época "era o casamento que possibilitava ao sexo feminino reconhecimento e posição". Ela tentava garantir seu futuro conjugal e social, pois permanecer solteira era ser um peso para a família, ficar num não-lugar social. A solteira era considerada "mulher deficiente" por não ter conseguido realizar a tempo o seu "destino biológico". Se tivesse sorte de se tornar uma agregada de algum parente da família - como já era Rosina seria uma espécie de empregada, porque a solteira não tinha o direito de ir aos bailes e saraus, não é mais moça casadora, nem mulher casada, seu lugar é ficar em casa cuidando das crianças, principalmente se não tiver herança que valha, "meio governanta, meio parente pobre". Vivia reclusa sob a vigilância das pessoas da mesma idade, dos mais velhos e dos mais jovens. Fazia as vezes de "cúmplice, protetora sacrificada e benévola" (STEIN, 1984, p. 64).

Em sua segunda fase, Machado desenvolverá a personagem feminina com força de cálculo que ensaiou em sua primeira fase (ASSIS, 1971a). Capitu que, desde a mocidade, é quem dirige a campanha que a leva ao casamento com Bentinho, consegue sair da posição de quase agregada, tornando-se 
membro da família abastada que vivia de rendas. Ela alcança contornar a promessa de D. Glória de fazer de Bentinho padre e ao mesmo tempo entra nas graças da família. Em seu caso, a força de cálculo não exclui espontaneidade de sentimentos. A diferença entre Capitu e os outros agregados, de acordo com Schwarz, está no fato de ela possuir opinião e pensamentos próprios, não estar disposta a ganhar compensações imaginárias e não querer viver sempre como uma dependente, mas se tornar uma proprietária. Queria o concreto e real do casamento e consideração pública, ser levada aos bailes e teatros e exibir sua beleza, elegância e opulência. Então, ela precisou encontrar caminhos e criar oportunidades para fazer com que seus desejos de promoção social fossem alcançados. Mais nítida, posto que menos envolta em ambiguidade, é a personagem Iaiá Garcia - do último romance da primeira fase machadiana. O descontentamento de Iaiá surge desde a infância, quando estudava em um colégio interno. No final de semana, ao retornar para casa, encontra um presente do pai, um piano novo, que ele comprou, apesar de a menina não ter muito talento, porque era sonho dela se tornar professora de piano. Ao ver o contraste entre o piano e a casa, Iaiá desmaia. Ela não suportaria viver naquela situação, ela mesma era o piano, destoante do resto da casa; precisaria da consideração e da cooptação de uma família abastada. A consideração chega, primeiro com a mãe de Jorge e com o dote que ela consegue através do afeto e da simpatia que despertou em Valéria. Depois chega a cooptação através do casamento com Jorge, objetivo que ela alcançou através de cálculo digno de um tabuleiro de xadrez, com estratégia e paciência, conquistando o coração do rapaz e a tão sonhada escalada social. Iaiá rompe com seu passado - morre-lhe o pai e afasta-se da madrasta - para com isso ser bem-aceita pelo mundo do qual o esposo faz parte.

Esta achou no casamento a felicidade sem contraste. A sociedade não lhe negou carinhos e respeitos. Se antes de casar, Iaiá possuía o abecedário da elegância, depressa aprendeu a prosódia e a sintaxe; afezse a todos os requintes da urbanidade, com a presteza de um espírito sagaz e penetrante. Nenhuma nuvem do passado veio sombrear a fronte de um ou de outro; ninguém se interpunha entre eles. Iaiá escrevia algumas vezes a Estela, que lhe respondia regularmente, e no mais puro estilo de família. (ASSIS, 1971b, p. 508) 
Não há espaço para dilemas e conflitos internos para essas moças, elas precisam ser resolutas em suas decisões. Era, portanto, preciso transpor as fendas que achavam nos muros erguidos entre as classes sociais. Na falta de heranças inesperadas, como era tão comum nos romances oitocentistas, se fazia imprescindível agarrar-se à imagem de um casamento que promovesse ascensão.

Machado, assim, afina a sua prosa com os problemas históricos de sua época. A localização temporal do conto, distante em duas décadas de seu momento de produção, ajudou a apreensão das contradições da sociedade brasileira, quando os primeiros elementos de um mundo liberal entraram em diálogo com o quadro vindo da Colônia. Da mesma forma, a sua conclusão irônica expressa, com certa melancolia, a noção de um conluio de forças cujos ecos talvez ainda hoje possam ser escutados.

\section{Referências}

ASSIS, Machado. Dom Casmurro. In: Obra completa. 3. ed. Rio de Janeiro: José Aguilar Editora, 1971a. v. I. Iaiá Garcia. In: Obra completa. 3. ed. Rio de Janeiro: José Aguilar Editora, 1971b. v. I.

Histórias da meia-noite. In: Obra Completa. Rio de Janeiro: Editora Nova Aguilar, 1986. v. II.

AZEVEDO, Thales. As regras de namoro à antiga: aproximações socioculturais. São Paulo: Editora Ática, 1986.

CHAlHOUB, Sidney. Machado de Assis, historiador. São Paulo: Companhia das Letras, 2003.

DICIONÁRIO DOS NOMES PRÓPRIOS. Disponível em: <https://www. dicionariodenomesproprios.com.br/ernesto/>. Acesso em: 21 fev. 2018.

FERNANDES, Florestan. A concretização da revolução burguesa. In: IANNI, Octávio (Org.). Florestan Fernandes. São Paulo: Ática, 2007.

FREYRE, Gilberto. Sobrados e mucambos: decadência do patriarcado e desenvolvimento do urbano. Apresentação de Roberto da Mata. 15. ed. São Paulo: Global, 2004. 
GÓGOL, Nikolai. O capote. Trad. Roberto Gomes. Porto Alegre: L\&PM Editores, 2000.

HOLANDA, Sérgio Buarque de. Raízes do Brasil. 26. ed. Companhia das Letras: São Paulo, 2004.

QUINTANEIRO, Tânia. Retratos de mulher: o cotidiano feminino no Brasil sob o olhar de viageiros do século XIX. Petrópolis: Vozes, 1995.

SCHWARCZ, Lilia Moritz; STARLING, Heloisa Murgel. Segundo Reinado: enfim uma nação nos trópicos. In:__ B Brasil: uma biografia. São Paulo: Companhia das Letras, 2015.

SCHWARZ, Roberto. Ao vencedor as batatas: forma literária e processo social nos inícios do romance brasileiro. 6. ed. São Paulo: Duas Cidades; Editora 34, 2012.

Um mestre na periferia do capitalismo: Machado de Assis. 4. ed. São Paulo: Editora 34, 2000.

A poesia envenenada de Dom Casmurro. In:

Duas meninas. São Paulo:

Companhia das Letras, 1997.

SOUZA, Gilda de Mello. O espírito das roupas: a moda no século XIX. São Paulo: Companhia das Letras, 1987.

STALLYBRASS, Peter. O casaco de Marx: roupas, memórias, dor. 3. ed. Organização e tradução de Tomaz Tadeu. Belo Horizonte: Autêntica, 2008.

STEIN, Ingrid. Figuras femininas em Machado de Assis. Rio de Janeiro: Paz e Terra, 1984.

NAIARA SANTANA PITA é mestre em Literatura e Cultura pela Universidade Federal da Bahia, na linha de pesquisa de Estudos e de Teorias e Representações Literárias e Culturais, com dissertação intitulada Dinheiro, amor e casamento: a formação do par amoroso em "Contos fluminenses" e "Histórias da meia-noite" de Machado de Assis. Este artigo é parte integrante de dissertação de mestrado, apresentada no Programa de Pósgraduação em Literatura e Cultura da Universidade Federal da Bahia (UFBA), e intitulada Dinheiro, amor e casamento: a formação do par amoroso em "Contos Fluminenses" e "Histórias da meia-noite de Machado de Assis. E-mail: naipita@hotmail.com

MIRELLA MÁRCIA LONGO VIEIRA LIMA é doutora em Teoria Literária e Literatura Comparada pela Universidade de São Paulo. Professora Titular de Teoria Literária e Literatura Comparada, atua nos cursos de Graduação e no Programa de Pós-Graduação em Literatura e Cultura do Instituto de Letras da Universidade Federal da Bahia (UFBA). 
Bolsista nível 2 do CNPq. Publicou "Cenas de Amor em Romances do Século XX", "Um Quarto Muito Amplo: memorial acadêmico" e "Confidência Mineira: o amor na poesia de Carlos Drummond de Andrade", entre outras publicações. E-mail: mirella@ufba.br

Recebido: 22.05.2018

Aprovado: 23.07.2018 